\title{
Roadworks: Automobility and belonging in Aboriginal art
}

\author{
Ursula Frederick
}

Life is old there

Older than the trees

Younger than the mountains

Growin' like a breeze

Country Roads, take me home

To the place I belong... ${ }^{1}$

\section{Introduction}

As a growing corpus of contemporary art reveals, automobility has a strong presence in Aboriginal cultural expression. The manner in which this theme is conveyed and what meanings these works communicate vary considerably across media, style and individual treatment. I would like to suggest that as a collective, these 'roadworks' might reveal as much about Aboriginal relations to 'Country' ${ }^{2}$ as any other Aboriginal art of place.

For several decades the concept of Country has played a pivotal role in the public discourse of Australian Aboriginality. It is a term that succinctly communicates the vast network of relationships that binds many Aboriginal people to their ancestry, their kin, their languages and their land in all its sentient creative capacity. In the context of Australian art, Country has been a particularly useful term (along with 'Dreaming') for describing the dominant theme of Aboriginal visual culture. It effectively encompasses a plethora of visual devices, formal properties, modes of representation and material substances as well as the underlying structures, stories and meanings that so many Aboriginal artworks

\footnotetext{
1 Denver, John, Nivert, Taffy and Danoff, Bill 1970, Take Me Home, Country Roads. Although originating within an American country-western genre, these lyrics aptly convey both the permanence and the ephemerality that I understand Aboriginal notions of Country to embrace. They also capture a sense of movement, journey and a longing for home. Inserting them here, I am gesturing to the importance of sound and music in augmenting experiences of automobility. As Michael Bull notes: ‘For many contemporary drivers the proximity of the aural now defines car habitation.' Bull, Michael 2004, 'Automobility and the power of sound', Theory Culture Society, vol. 21, p. 246.

2 Where I use the term Country in association with Aboriginal Australia, it is capitalised; in other contexts, it is not.
} 
convey. ${ }^{3}$ In this essay, I intend to explore how Country is represented through Aboriginal arts of automobility via visual analysis of specific paintings by four Aboriginal artists from rural and urban Australia.

I begin by introducing a variety of works by Aboriginal artists that incorporate automobility in different ways. I then focus on individual paintings by Christopher Pease (b. 1969), Lin Onus (1948-96) and Revel Cooper (c. 1934-83). Finally, through the work of the artist Ian Abdulla (1947-2011), I explore the art of automobility as an artist's theme, considering the interrelated complexities of automobile subjectivity, Aboriginality and Country his oeuvre evokes. Before entering into a discussion of the art of Aboriginal automobility, it is useful to consider the role of Country in Aboriginal art and the experience of automobility in Aboriginal Australian history.

\section{Mapping a Road to Country}

In the Australian context, country is a word that commonly denotes either rural living or the nation-state. In recent decades, the term Country has also emerged as a key concept in defining and describing Aboriginal relations to land and identity. In its Aboriginal usage, the word Country embraces places, ecologies, kin, Law, beliefs, ways of being, a world view and a system of meaning. ${ }^{4}$ Although difficult to define in this context, ${ }^{5}$ as a gloss word Country may stand in for Indigenous language terms that signify specific places, tracts of land and, by association, a vast network of traditions and relationships. In other words, in usage, Country may be both abstract and very particular. In both senses, Country is something to which people belong. Consequently, in a very real way, Country can nourish the individual as well as distinguish and bind collectives of people. In post-Mabo ${ }^{6}$ Australia, Country can carry a particular resonance

\footnotetext{
3 I do not mean to suggest that all Aboriginal art is explicitly about Country. It could be argued that, aside from what Aboriginal art means, it concerns Country because of the contemporary state of Australian politics. 4 Sutton, Peter 1996, Country: Aboriginal boundaries and land ownership in Australia, Aboriginal History Monographs (ANU), Canberra; Bonyhady, Tim and Griffiths, Tom 2002 'Landscape and Language' in Tim Bonyhady and Tom Griffiths (eds) Words for country: landscape \& language in Australia, Sydney, UNSW Press, pp. 1-13.

5 My intention here is to provide a sense of the term rather than a clear definition. For some discussion of the tensions inherent in applications of 'Country', see Due, C. 2008, 'Laying claim to "country": native title and ownership in the mainstream Australian media', M/C Journal, vol. 11, no. 5; Goodall, Heather 1999, 'Telling country: memory, modernity and narratives in rural Australia', History Workshop Journal, no. 47 (Spring), pp. 160-90; Sutton, Country.

6 The term 'post-Mabo Australia' refers to a significant turning point in the history of Australian landrights legislation in which the High Court ruled in favour of Eddie Mabo. This judgment, which occurred in 1992, 'recognised for the first time that Australian Aborigines and Torres Strait Islanders had ancestral rights to land dating from before European settlement'. Oxford English Dictionary 2000, 'Mabo', Oxford English Dictionary, [Third edition], March, Online version viewed 29 September 2011, <http://www.oed.com/view/ Entry/243865>
} 
with regard to the recognition and exercise of native-title rights and obligations, and in this allusion to the nation-state the term enfolds aspirations and claims to Indigenous sovereignty.

As an evocative and encompassing term, Country has been used across a variety of projects and programs implemented by individuals as well as public and private sector institutions, from local communities to government departments and universities. In the past decade alone, Country has been created, crossed, cruised, cared for, contested, pierced, painted and spoken. ${ }^{7}$ The creative arts industry in Australia has become a strong advocate for the use of the word Country as a structural framework for ordering the production, analysis, display and dissemination of contemporary Aboriginal art. ${ }^{8}$ For the most part, artists and arts workers recognise that Country is at the heart of much Aboriginal arts practice, cultural identity and sense of belonging. More than this, it is acknowledged that art as and of Country can operate as a site for the production and communication of Aboriginal beliefs, knowledge and identity.

I suggest that by reiterating the term Country, various art exhibitions, catalogues and essays on Aboriginal art have worked to normalise an Indigenous framework of belonging that further discredits the colonial concept of terra nullius. ${ }^{9}$ In this respect, country might mutually imply 'Australia' and rural life but it also acknowledges the existence of territories inhabited prior to colonial settlement. As Peter Sutton plainly puts it: 'In Aboriginal terms, all landscape is someone's home.' ${ }^{10}$

In considering how Country might be read through artistic expressions of automobility, it is worth looking at how Country is situated in Aboriginal art more broadly. This can be examined through various disciplinary perspectives (including anthropology, archaeology and art history) and through different scales and ranges of production, via consideration of exhibitions and individual artworks. Strategies might include comparison of works with stylistic or thematic similarities within an artist's oeuvre, art-centre practice or from common community/kin groupings.

\footnotetext{
7 Some recent examples of this usage include the exhibition Crossing Country at the Art Gallery of New South Wales, and the Landcare program Caring for Country.

8 It might also reflect a growing public familiarity with the term as an identifier of Indigeneity.

9 The Latin terra nullius (land belonging to no-one) is used in international law to refer to territory that has not been subject to ownership by a sovereign state. In the Australian historical context, its use denied prior Aboriginal occupation and was used as a justification for British claims to and settlement of the land. 10 Sutton, Peter 1988, 'Dreamings', in Peter Sutton (ed.), Dreamings: The art of Aboriginal Australia, Penguin, Ringwood, Vic., p. 17.
} 


\section{Country in the Presentation of Aboriginal Art}

Given what Country entails, one might argue that there is no better conceptual lens through which to view Aboriginal art. ${ }^{11}$ While it is certainly a very popular application, Country offers far more than curatorial convenience and a catchy title. It is the underlying logic that motivates many Aboriginal arts and crafts practices, past and present. Over the past two decades, anthropologists, art historians and gallery professionals have deployed the language of Country in their research, curation and writing about Aboriginal art. Country is used as a theme to structure exhibitions in a more or less direct fashion. Curatorial projects have focused on particular sites or land formations (such as Jilji) ${ }^{12}$ or on the forces and figures that emanate through them (such as Wandjina ${ }^{13}$ and Gwion Gwion). ${ }^{14}$ Specific motifs have been used to thematically link artworks by different artists. Likewise, the representations of a single motif or object can allude to a specific Country and cultural group. There is a capacity for some figures to symbolise the unification of a region while also accommodating group difference, as in the case of the Rainbow Serpent Yingarna. ${ }^{15}$ Such motifs are a contributing factor in social cohesion and reveal an important nexus between art, Country and people.

Presenting the art produced from a single community, regional art centre or movement is a common approach to the curation of Aboriginal art. This can have the effect of presenting one Country through many eyes, revealing both synergies and diversity in artistic styles. ${ }^{16}$ Perhaps a more novel exercise in the context of Aboriginal art is the development of retrospectives, such as those for Bardayal 'Lofty' Nadjamerrek ${ }^{17}$ and Emily Kame Kngwarreye, ${ }^{18}$ which effectively chart a single individual's renderings of their Country over the course of their artistic life. This curatorial method not only allows the viewer to observe an artist's changing practice, it also offers multiple views of the same Country and therefore enables different sensorial engagements. River, Land, Memory, an early retrospective of Ian Abdulla's work, follows a related temporal framework that

11 This is particularly the case where Country is positioned to intersect with the concepts of Law and Dreaming, and their Aboriginal language equivalents.

12 Jila, Jilji and Miyi - Mangkaja Arts, 2007, Cool-Art Gallery, Coolum Beach, Qld.

13 Stanton, John 2006, 'Wandjina', Art \& Australia, vol. 43, no. 3, pp. 414-19.

14 Mowanjum Artists - New works in ochre, 15 October - 17 November 2010, Japingka Gallery, Fremantle, WA.

15 Taylor, Luke 1990, 'The Rainbow Serpent as visual metaphor in Western Arnhem Land', Oceania, vol. 60 , no. 4 (June), pp. 330-44.

16 A regional approach to the display of Aboriginal art is perhaps the most common nod to 'Country' employed by galleries and museums, including the recently opened Indigenous art wing of the National Gallery of Australia.

17 Bardayal 'Lofty' Nadjamerrek AO, 10 December 2010 - 20 March 2011, Museum of Contemporary Art, Sydney.

18 Utopia: The genius of Emily Kame Kngwarreye, 22 August - 12 October 2008, National Museum of Australia, Canberra. 
offers one artist's outlook on the SA Riverina. In a less direct manner, some exhibitions have sought to highlight the linkages across geographies and between peoples, through the existence of sprawling narratives and ancestral journeys (Wagilag Sisters).${ }^{19}$ More recently, this focus on Country has embraced colonial landscapes such as the Canning Stock Route ${ }^{20}$ and facilitated return to Country. It has also generated cross-cultural collaborations, such as that between Yolngu and balanda (non-Yolngu) in Djalkiri: We are standing on their names. ${ }^{21}$ Other scholars and exhibitions have emphasised the formal expression of power that is evident in Country. Howard Morphy, for example, has written extensively on bir'yun - the visual effect of shimmering that endows Yolngu painting with power, and which can also have specific connotations 'depending on the clan and Ancestral Being concerned'. ${ }^{22}$

At the same time, an artwork can embody the physical fabric of Country. Artists might incorporate these materials figuratively, as in Christian Thompson's photographic series Australian Graffiti (2008). Or they might be tangibly embedded in the work itself. Natural pigments, bark, grasses, shell and stone are all material links to Country. Julie Gough has described collecting such materials together as a way of marking associations between places of personal experience. ${ }^{23}$ The use of organic substances and their associated place and cultural meaning are occasionally incorporated within the exhibition space through audio, video and other multimedia displays. ${ }^{24}$ Furthermore, methods of procurement, the cultural knowledge and protocols of place, and the social relations of hunting or gathering might be the basis of the artwork itself, as with Ricky Maynard's photographic essay on mutton-birding in Tasmania. ${ }^{25}$

Many curatorial endeavours use place as an anchor for exploring the linkages between the past and the present and for emphasising the importance of remembering. Thus, in a recursive sense it is acknowledged that speaking of and about Country, in text, paint and voice, are important practices for the

19 Caruana, Wally and Lendon, Nigel 1997 (eds), The Painters of the Wagilag Sisters Story 1937-1997, [Exhibition catalogue], National Gallery of Australia, Canberra.

20 Yiwarra Kuju: The Canning Stock Route, 30 July 2010 - 26 January 2011, National Museum of Australia, Canberra.

21 We Stand on the Footprints of the Old People, Film [34 min.], Morphy, Howard and Frederick, Ursula 2011, Djalkiri: We are standing on their names, Blue Mud Bay touring exhibition, produced by Nomad Art.

22 Morphy, Howard 1989, 'From dull to brilliant: the aesthetics of spiritual power among the Yolngu', Man, vol. 24 , no. 1 (n.s.), p. 29.

23 See Gough, Julie 2005, abstractions, viewed 4 February 2011, <http://www.anu.edu.au/culture/ abstractions/artists/jg_1.htm>

24 See, for example, tayenebe at the Tasmanian Museum and Gallery, viewed 23 March 2011, < http://static. tmag.tas.gov.au/tayenebe>; Gough, abstractions. A particularly stunning convergence of media is evident in the bark-video work Djalkiri \#1 and \#2 produced by Susan Marrawakamirr, David Gurrumurruwuy Bukulatjpi and Jennifer Deger (viewed 29 September 2011, <http://www.niea.unsw.edu.au/culture-andsociety/projects/djalkiri-1-and-djalkiri-2>).

25 Taylor, Penny (ed.) 1988, After 200 Years: Photographic essays of Aboriginal and Islander Australia today, Australian Institute of Aboriginal Studies, Canberra. 
ongoing production and maintenance of cultural knowledge. And of course Aboriginal art has served a powerful political role as a form of protest and diplomacy (the Bark Petition), ${ }^{26}$ and as testimony of Aboriginal rights to land and sea (Saltwater). ${ }^{27}$

Alongside these ancestral geographies, we might also find group exhibitions that evolve out of places constructed under the framework of European colonisation: pastoral stations, mission towns and colonial settlements. Carrolup, Ngukurr, Ntaria (Hermannsburg), Papunya and Warburton are each in their own way important loci of artistic activity, although the country that inspires their work extends far beyond the reach of their communities. It is in such centres that the expansive and visionary qualities in Aboriginal art are often most evident. Here we see how people are able to reach out for Country in their minds and then picture it on the canvas or page. Aboriginal artists often paint Country in this 'extended' way - that is, from a spatial or temporal distance from the Country being depicted. ${ }^{28}$

In summary, there are many ways that Country can be expressed through art. It can be depicted at varying scales, spatially and temporally. It might appear pictorial or it might be abstract. The motivations behind its production are varied and often multifunctional, just as it might communicate different meanings through multivalency. It is important to recognise that the art-making process in itself can also be a mode for connecting with place. The examples I have offered give some indication of how Aboriginal art can express an engagement with Country. This in turn provides a context for considering how Country might be experienced automotively.

\section{Automobility in Aboriginal Australia}

Insofar as it 'opened up' the outback for sustained exploration and settlement, the car might be viewed as a colonising agent and an extension of colonial

\footnotetext{
26 For a synopsis of the Bark Petition, see Morphy, Howard 2000, 'Arts and politics: the bark petition and the Barunga statement', in S. Kleinert and M. Neale (eds), Oxford Companion to Aboriginal Art and Culture, Oxford University Press, Melbourne, pp. 100-2.

27 Saltwater: Yirrkala bark paintings of sea country, 30 June - 1 October 2007, Australian National Maritime Museum, Sydney.

28 Contemporary artists sometimes remark of painting Country they have not visited recently, or ever. This process might be considered a form of memory work or imagining. Yet because the 'distance' overcome is not always or only temporal, I prefer to think of these actions as reflecting a practice of 'travelling' through art or mark making. This process might well be akin to other ways of 'travelling' to visit or maintain Countrysee, for example: Tonkinson, R. 1970, 'Aboriginal dream-spirit beliefs in a contact situation: Jigalong, Western Australian', in R. M. Berndt (ed.), Australian Aboriginal Anthropology: Modern studies in the social anthropology of the Australian Aborigines, University of Western Australia Press, Nedlands, pp. 277-91.
} 
administration. ${ }^{29}$ It is well known that the car is a symbol of modernity and that Aboriginal societies suffered under systems of governance in which modernity flourished. The system of automobility made Aboriginal lands and people more accessible to outsiders because with more roads and cars came more settlers, missionaries, miners, tourists and government officials wanting to see, use and at times control Aboriginal people, their land and their resources. Thus, as a set of historical policies and practices, the project of automobility might be seen to have worked against Indigenous people and their ongoing claims to land and sovereignty.

Not only have motor vehicles facilitated access to land by non-Indigenous peoples, road travel is also one of the ways by which white belonging is enacted. ${ }^{30}$ Roads, highways, petrol stations and motels normalise the occupation and governance of land by non-Indigenous authority and capital. Roads divide land into bounded entities and predetermined pathways maintained and controlled by government agencies. Moreover, the myth of terra nullius is perpetuated symbolically in the 'explorer' and 'discovery' tropes regularly used in the automotive advertising sector. Clearly, in the context of Aboriginal Australia, issues of automobility are tethered to tensions that are extant in the histories and contemporary politics of Australia.

The technology of the car facilitated racist policies and procedures in other ways. Cars were one instrument used in the administration of assimilationist policies, including the removal of Indigenous children from their families, until the 1970s. Laurel Nannup's woodcut Leaving Home depicts the day a big, black car took her and her sister from their home to Wandering Mission. ${ }^{31}$ The print is one of many heartbreaking recollections from the Stolen Generations era. Ngunnawal elder Matilda House's memory of being woken by an engine rumbling in the early hours of the morning is another harrowing example. ${ }^{32}$ While the consequences of this history are still being felt, automobility presents another raft of issues for Aboriginal people today. In addition to the associated issues of petrol sniffing (see Brady, this volume), car theft and negative stereotyping, the relatively high incidence of road fatalities and injury amongst the Aboriginal population are of major concern. ${ }^{33}$

29 It is must be noted that other technologies of movement were involved in a long and complex process of exploration, dispersal, emigration and settlement. Jeremy Long's account gives some insights on the matter: Long, Jeremy 1989, 'Leaving the desert: actors and sufferers in the Aboriginal exodus from the Western Desert', Aboriginal History, vol. 13, no. 1, pp. 9-44.

30 Note, for example, the strong connections in advertising between off-road access via four-wheel-drives and utes as ways of normalising non-Aboriginal use of land.

31 Dictionary of Australian Artists Online: <http://www.daao.org.au>

32 House, Matilda 2005, Welcome to Country speech delivered to the Cruising Country Symposium, Canberra, The Australian National University, May 25.

33 Aboriginal Australians are over-represented in statistics relating to road deaths and injuries. In recognition of this fact, many States have developed road-safety programs and strategies aimed at the 
I mention these matters because they are a valid counterweight to the more popular image of the car as a symbol of freedom. ${ }^{34}$ In recent years scholars have mounted compelling arguments for why we need to rethink the association between liberty and driving. ${ }^{35}$ There are in fact significant equity issues and contradictions to note. Yet I do not want to ignore what Gilroy calls the "popular pleasures of auto-freedom-mobility, power, speed' ${ }^{36}$ Nor do I want to lose sight of the practical realities of automobility's benefits. In fact, by attending to its presence in art, we might be able to critically examine both the opportunities and the dangers the road presents. But before we look at how some Aboriginal artists picture their relationships to the road, I examine some of the associations between automobility, Aboriginality and Country raised in previous studies.

The field of study identified as 'automobilities' research is a relatively new arena of scholarship. As Frederick and Stefanoff (this volume) outline, much of this work has emerged from Europe and the United States and reflects what Featherstone describes as a broader interest in the 'flows, movement and mobility in social life'.$^{37}$ Consequently, much automobilities research is concerned not only with the car but also with the cultures, spatialities and materialities that the automobile enables and affords.

Though few Australian researchers currently recognise the conceptual parameters of the new automobilities framework, ${ }^{38}$ several have explored different aspects of car culture in Aboriginal Australia. Much of this work derives from a single discipline: anthropology. The majority of ethnographic observations are made in the context of larger fieldwork programs rather than specifically car-focused studies. Nevertheless, they present useful insights into the social functions

Indigenous population. See: Thomson, N., Krom, I. and Ride, K. 2009, 'Summary of road safety among Indigenous peoples', Healthinfonet, <http://www.healthinfonet.ecu.edu.au/related-issues/road-safety/ reviews/our-review>

34 In the context of Aboriginal Australia there are grounds for suggesting that automobility might be perceived as a tool towards self-determination. See, for example, the Mutuka Project: <http://www.palyafund. org.au/projects/link/Mutuka.aspx> (viewed 8 October 2011).

35 Seiler, C. 2008, Republic of Drivers: A cultural history of automobility in America, University of Chicago Press, Chicago; Paterson, M. 2007, Automobile Politics: Ecology and cultural political economy, Cambridge University Press, Cambridge.

36 Gilroy, Paul 2001, 'Driving while black', in D. Miller (ed.), Car Cultures, Berg, Oxford, p. 89.

37 Featherstone, Mike 2004, 'Automobilities: an introduction', Theory, Culture \& Society, vol. 21, nos 4-5, p. 1.

38 Notable exceptions include historian Georgine Clarsen and film and cultural studies scholar Catherine Simpson. 
and meanings of vehicles in Arnhem Land, ${ }^{39}$ Central Australia ${ }^{40}$ and northern Western Australia. ${ }^{41}$ They discuss how the motor vehicle is used and explore its symbolic and utilitarian currencies.

Like other items introduced by non-Aboriginal cultures, the motorcar is observed in Aboriginal mythology, ${ }^{42}$ and in a pragmatic sense it serves the practice of Aboriginal ceremony. In fact, Peterson has argued that increased access to the car in Central Australia, beginning in the 1970s, facilitated the reproduction of an expanded regional sociality based on male initiation ceremonies. ${ }^{43}$ He points to the great pleasure men receive from travelling and the importance of journeying in Western Desert religiosity and social dynamics. In suggesting that through 'the extension of the initiation journey the greater Western Desert is gradually being integrated into a common moral community', ${ }^{44}$ Peterson effectively demonstrates the role automobility has had in reshaping the social contours of Country. Recursively, Gerrard identifies how the 'establishment of outstations has also created Aboriginal dependence on motor transport' ${ }^{45}$ Speaking in the context of a specific Arnhem Land community, Gerrard examines how various social mechanisms are employed to overcome a chronic shortage of motor vehicles. ${ }^{46}$ Myers and Stotz similarly explore vehicle access as a resource. ${ }^{47}$ Stotz's work highlights the gender relations of Walpiri automobility, and she argues that ownership of a community Toyota is a male privilege. Significantly, this privilege is asserted, she suggests, by linking control over the vehicle with traditional rights to land. ${ }^{48}$

Stotz's ethnography makes a number of interesting observations regarding mobility, space and time and the effect the 'Toyota' has had in their social

\footnotetext{
39 Hinkson and Altman describe the many social uses of the vehicle within Maningrida. Altman, Jon and Hinkson, Melinda 2007, 'Mobility and modernity in Arnhem Land: the social universe of Kuninjku trucks', Journal of Material Culture, vol. 12, no. 2. Fogarty examines the competing uses of the vehicle in the context of education delivery in remote Aboriginal communities. Fogarty, William 2005, 'You got any Truck?' Vehicles and decentralised mobile service-provision in remote Indigenous Australia, Working Paper No. 30, Centre for Aboriginal Economic Policy Research, The Australian National University, Canberra.

40 Young, Diana 2001, 'The life and death of cars. Private cars on the Pitjantjatjara Lands, South Australia', in D. Miller (ed.), Car Cultures, Berg, Oxford, pp. 35-59; Stotz, Gertrude 1993, Kurdungurlu got to drive Toyota: differential colonizing process amongst the Walpiri, unpublished $\mathrm{PhD}$ thesis.

41 Anthony Redmond (this volume).

42 Lommel, Andreas 1950-51, 'Modern culture influences on the Aborigines', Oceania, vol. 21, p. 23.

43 Peterson, Nicolas 2000, 'An expanding Aboriginal domain: mobility and the initiation journey', Oceania, vol. 70, no. 3 (March), pp. 205-18.

44 Ibid., p. 212. For a recent response to this material, see Curran, G. 2011, "The "expanding domain" of Warlpiri initiation rituals', in Y. Musharbash and M. Barber (eds), Ethnography and the Production of Anthropological Knowledge: Essays in honour of Nicolas Peterson, ANU E Press, Canberra.

45 Gerrard, G. 1989, 'Everyone will be jealous for that mutaki', Mankind, vol. 19, no. 2 (August), p. 100.

46 Gerrard focuses on one key mechanism to acquire motor vehicle access - that is, humbugging (ibid.).

47 Myers, Fred 1989, 'Burning the truck and holding the country: Pintupi forms of property and identity', in E. Wilmsen (ed.), We Are Here: Politics of Aboriginal land tenure, University of California Press, Berkeley, pp. 15-42; Stotz, Kurdungurlu got to drive Toyota.

48 Stotz, Kurdungurlu got to drive Toyota, pp. 2-3.
} 
reproduction and negotiation amongst the Walpiri. Of relevance here is her identification of the space inside the car and how seating arrangements continue to reflect the social ordering of Walpiri space. ${ }^{49}$ She goes on to suggest that the small private vehicle is much like a portable camp used by a single family. Following this, Diana Young outlines some of the ways in which the car is used as an architectural support in Pitjantjatjara camps. ${ }^{50}$ If the socio-spatial relations delineated in reference to Country and kin outside the vehicle are also enacted within the car, it might then follow that in some situations the interior space of the vehicle is also experienced as a kind of Country.

This sensibility - of Country permeating the interior space of the motorcaris captured in a scene from Beneath Clouds, ${ }^{51}$ a feature film by Aboriginal filmmaker Ivan Sen. Towards the end of the film, the two protagonists, Lena and Vaughn, hitch a ride. Close shots of the faces inside the car are spliced with views from the distinctive landscape outside. The passengers look up to a cliff that was likely an Aboriginal massacre site. An older Aboriginal lady breaks the silence: 'Where are your people from, girl?' she asks the young Lena, whom she now sits beside. Which is to say where is your Country, who are you? This performance of place-making and identity association within the space of the car is an example of how automobility can be experienced simultaneously as processes of movement and anchoring. ${ }^{52}$

Although we generally associate a connection to place with fixity, this scene also suggests that the sense of stability that comes with belonging is actively created rather than static. The idea that something can be stable while in motion is also a sensorial experience of driving. It is perhaps this feeling that Jacky Tjupuru communicates when he describes his first ride in a motorcar, about 1930: 'We climbed in straightway and we were sitting there...He took us away and I was ignorantly thinking that we were still sitting at the camp, but I saw the camp moving away in the distance. It was as if we were sitting there making a noise. ${ }^{53}$

This vignette reveals one man's reflection on his first experience of automobility. ${ }^{54}$ Other early encounters between Aboriginal people and motor vehicles are

\footnotetext{
49 P. J. Deloria makes a similar observation for Native Americans for whom 'cars easily served as mobile housing, reprising the older functions of both horse and tipi... Within the car Indian families sometimes replicated the social arrangements of the tipi or other lodging'. Deloria, P. J. 2009, 'I want to ride in Geronimo's Cadillac', in J. A. Radway, K. Gaines, B. Shank and P. Von Eschen (eds), American Studies: An anthology, WileyBlackwell, Chichester, UK, pp. 419-20.

50 Young, 'The life and death of cars'.

51 Sen, Ivan (dir.) 2002, Beneath Clouds.

52 Motion, place and kinship are reiterated and symbolically bound in several scenes within this film.

53 Tjupuru, Jacky and Edwards, Bill 1994, 'Mutuka Nyakunytja - seeing a motorcar', Aboriginal History, vol. 18, no. 2 , pp. 145-58.

54 I am conscious that the coupling of Indigenous peoples with technology as symbols of modernity has also had a problematic history. As Gelder points out, it 'can be a way of invoking Aboriginal naivety'. Gelder, K.
} 
recorded visually in rock art ${ }^{55}$ and photography. ${ }^{56}$ Documentary films ${ }^{57}$ offer another representational format for the automotive experiences of Aboriginal people. And alongside Sen's feature there are several fiction films incorporating Aboriginal stories within the road genre. ${ }^{58}$ In addition to the films themselves, there is a growing body of scholarship that examines Aboriginal automobility as represented in film and television. ${ }^{59}$

\section{Automobility in Aboriginal Art}

There is no doubt that cars have played a key role in postwar Australian life so it is hardly surprising that automobiles feature strongly in Aboriginal art. Despite the prevalence of automobility in Aboriginal Australia very little has been written about it in relation to Aboriginal art. The few exceptions ${ }^{60}$ in the literature each demonstrate how vehicles might be entwined with Aboriginal art movements, and as objects that mediate exchange and social values. ${ }^{61}$ This research has, however, been more concerned with addressing the social mechanics of art production than in detailing individual works. Diana Young

1998, 'Mad Max and Aboriginal automation: putting cars to use in contemporary road films and narratives', in D. Thoms, L. Holden and T. Claydon, The Motor Car and Popular Culture in the 20th Century, Ashgate, Aldershot, UK, p. 63. Also see Deloria, 'I want to ride in Geronimo's Cadillac'.

55 An engraving of a motorcar appears at the Granites, Northern Territory.

56 See, for example: Batty, P. (ed.) 2006, Colliding Worlds: First contact in the Western Desert, 1932-1984, [Exhibition catalogue], Museum Victoria, Melbourne; The Francis Birtles motor car tour collection, ca. 18991928, Album of photographs, National Library of Australia, Canberra. The portrait of Albert Namatjira with his truck is another significant example - see: Croft, Brenda 2001, 'Albert's gift', [Catalogue essay], Indigenous Art, Art Gallery of Western Australia, Perth.

57 For example: Dunlop, Ian (dir.) 1995, Conversations with Dundiwuy Wanambi; and MacDougall, David (dir.) 1986, Transfer of Power.

58 For example: Noyce, Phillip (dir.) 1977, Backroads; Lander, Ned (dir.) 1981, Wrong Side of the Road; McGregor, Steven (dir.) 2003, Cold Turkey.

59 These studies come from a number of disciplinary perspectives including history, film studies, anthropology and cultural studies. For an analysis of Central Australian Aboriginal film and television see Stefanoff, L. 2009, (C) CAAMA Productions: listening, revelation and cultural intimacy at the Central Australian Aboriginal Media Association, unpublished PhD thesis, New York University, New York; ProbynRapsey, F. 2006, 'Bitumen films in postcolonial Australia', Journal of Australian Studies, vol. 88, pp. 97109; Venkatasawmy, R., Simpson, C. and Visosevic, T. 2001, 'From sand to bitumen; from bushrangers to "bogans"; mapping the Australian road movie', Journal of Australian Studies, vol. 70, pp. 75-84, 161-3; Simpson, C. 2006, AAntipodean automobility and crash: treachery, trespass and transformation of the open road', Australian Humanities Review, nos 39-40 (September). For analyses of Aboriginality in Mad Max, see Morris, M. 1998, 'White panic or Mad Max and the sublime', in Kuan-Hsing Chen (ed.), Trajectories: InterAsia cultural studies, Routledge, London and New York.

60 Myers, 'Burning the truck and holding the country'. Other papers (and first presented at Cruising Country) include Altman and Hinkson 'Mobility and modernity in Arnhem Land'; Johnson, V., Kean, J., Long, J. and Thorley, P. 2007, Mutukayi: public conversation on motor cars and Papunya painting, 2 December, National Museum of Australia, Canberra.

61 Myers, 'Burning the truck and holding the country'. 
makes several interesting observations on the relationship between cars and mark-making processes. One of these is her reading of Anmatyerr artist Mavis Holmes Petyarr's painting on a car door:

The head of a person is painted on the window as though going along inside the car, and red and green country-rocks, trees, earth-is depicted on the metal paintwork part of the door. I imagine that the artist was showing how the travel of the car through that country had transformed both the vehicle and those inside it through access to ancestral power - that is, through access to country. ${ }^{62}$

Young's account, along with the other examples from the Anangu Pitjantjatjara Yankunytjatjara Lands that she provides, suggests a unique insight into how the car, people, community and Country can be mutually transformed. She also relays how an Anangu history of roads - as human marks made on Country - is told as people are moving through the landscape: 'These things are generally spoken of as they are passed.'63 And these 'things' that Young writes of reveal an intimate Anangu knowledge - of roads, potholes, curves and 'events that happened on the road' ${ }^{64}$ — which effectively equates to a knowledge of Country.

As in the work described by Young, some Aboriginal artists incorporate the car's fabric as a material support. A series of bonnet paintings from the Western Desert Patyarr community is amongst this kind. There are many examples of artists using the car as a motif. The almost full-scale grass Toyota truck woven by the Tjanpi Desert weavers is an outstanding fibre-art sculpture that won the 2005 National Aboriginal and Torres Strait Islander Art Award. In some instances, the motor vehicle and the road become recurrent motifs, as in recent works by Billy Kenda. Or, for example, the light trucks and wide-angle roads in many of Jenny Broun's paintings. In this regard the vehicle is an explicit part of the work's composition and narrative, and reflects her individual experience. 'Those experiences of [being] in the bush, especially traveling, is a big part of my life. ${ }^{65}$ In other works, the car is a feature of the world the artist is depicting: motor vehicles are prevalent in a diverse range of areas from Ellen Jose's suburban mise en scène to the 'history paintings' of Ngaanyatjarra Lands ${ }^{66}$ Yet the car also features in more radical formulations as in A painting for the underdawg (2005), one of Gordon Hookey's characteristically confrontational pieces. It is a comicpolitical play on words that incorporates anthropomorphised native animals as protagonists. A dingo driver with his passengers hoons across the canvas in

62 Young, 'The life and death of cars', p. 43.

63 Ibid.

64 Ibid.

65 Broun, quoted in Stanton, J. E. 2004, On track: contemporary Aboriginal art from Western Australia, Occasional Paper No. 6, Berndt Museum of Anthropology, University of Western Australia, p. 59.

66 History Paintings: All the stories got into our minds and eyes, [Exhibition catalogue], 6 May - 3 June 2011, Darwin. Outstation - art from art centres and Warakurna Artists. 
a souped-up, jet-engine-propelled car. The painting is a response to negative stereotyping of Aboriginal people and their cars and linked to an exhibition called Ruddock's Wheel. ${ }^{67}$

There are many other examples of cars featuring in contemporary Aboriginal art. ${ }^{68}$ Although the car is an important symbol of automobility, automobility itself cannot, however, be reduced to the motor vehicle. In the section that follows, I turn my attention to the road.

\section{On the Road}

Of the numerous 'roadworks' that exist in the corpus of Australian Aboriginal art, there are many that do not include cars. Some of these are 'abstract' works, such as the landscapes painted by Queenie MacKenzie and Freddie Timms. Their contemporary Rover Thomas (Joolama) is responsible for perhaps the most well-known 'roadwork' of all: Roads Meeting (1987). In a figurative sense, this painting appears as a landscape depicting the intersection of two roads: one red dirt, the other bitumen. At each side of the canvas, nested in the fork of the two roads, there is a hand with forearm reaching towards the central crossing of the paths. In their symbolic capacity, the two roads reflect the 'two ways' of Australia's Indigenous and non-Indigenous cultures, coming together but maintaining their own integrity. As an expression of Country, Thomas's painting would appear to show these two cultures inhabiting the one land. Given the date of the work's production - in the year prior to Australia's bicentenary-Thomas might also have been suggesting that Australia was at a crossroads in time.

For the purposes of comparison, the three artworks I have chosen for closer considered attention share a realist approach. Unlike the 'abstract' roadworks from Warmun and elsewhere, the selection of paintings I discuss below-by Nyoongar artists Revel Cooper and Christopher Pease and Yorta Yorta artist Lin Onus-employ a detailed pictorial mode. ${ }^{69}$ Another feature shared by these paintings is that the road is a key character in both the narrative and the

\footnotetext{
67 Many of Hookey's works directly protest racist statements about Aboriginal people circulating in the media and political arena. Hookey is not afraid to address this racism in clever puns and (often crude) colourful imagery. Ruddock's Wheel is worth noting because the painting and exhibition are responses to a remark made by Federal Government Minister Phillip Ruddock who stated with regard to contemporary Indigenous Australians: 'We're dealing with people who are essentially hunter-gatherers. They didn't have chariots. I don't think they invented the wheel.' Australian Broadcasting Corporation (ABC) 2000, 'Ruddock under fire from Democrats, Labor and Greens', PM, 5 October, ABC Radio, viewed February 2011, <http:// www.abc.net.au/pm/stories/s196112.htm>

68 There are too many examples to name here; some include work by June Richards, H. J. Wedge and Badger Bates.

69 In making this selection, I am aware that the artists responsible - Revel Cooper, Lin Onus and Christopher Pease - share some social and historical connections beyond the aesthetic connections seen in their art: Onus
} 
composition, although it appears quite differently in each work. In Cooper's painting, the road is central and bold, yet it is enveloped by dense bush. Onus's road is subtle and symbolic; it doubles as a snake reflected in the side mirror of an unseen vehicle. In Pease's composition, the road is the land, filling the entire ground on which the figure of a Nyoongar man stands. Yet in all three paintings the viewer is provided with a strong sensation of being on the road. The vehicle is implied rather than seen. An 'on the road' point of view is devised by the artist so that the viewer is located in the space of the car and the position of the driver. In this sense, the artist and viewer share the same road and the same view of Country.

\section{Country Roads: South-West Landscape near Pemberton (c. 1962)}

In his painting South-West Landscape near Pemberton, Nyoongar artist Revel Cooper depicts a lush landscape of tall gums, grass trees and other native vegetation. The trees stand straight and strong, with white trunks and verdant foliage. The ground is a warm-yellow, rock-scattered surface that rises steeply to hills in the background. Only a small sweep of sky can be seen, slipping between the high terrain of land and a rich canopy of leaves and branches that crowds the foreground. The forest frames the scene, enveloping every edge and corner, but for a bold band of black that sprouts from the very bottom of the image.

The central position and open space of the road provide some interruption, but, rather than cleaving or competing with the adjacent flora, the road provides a visual respite to the vibrant and congested detail of the surroundings. In return, its stark presence is softened by amber hues. This point of view holds viewers and the artist together, hovering directly above the road. The eye cannot help but follow this line as it curves its way into the hills. If one traces its route, we pass native forest and clearings. We witness kangaroos alert and unfettered in the foreground and in the middle ground we find horses grazing in an enclosure adjacent to a small farmhouse. Beyond this the road climbs through the hills to a point in the distance before it suddenly becomes absorbed by the forest.

Cooper has painted the road as a trajectory winding through the landscape, and this lends the scene a temporal quality and narrative anticipation. We are on a journey of some kind. Where will this road take us? What is beyond the hills? How far are we going? When will we stop? Although the painting is unique, it is one of a number of paintings that Revel Cooper made of the landscapes of south-western Australia, his home. Born in the town of Katanning, Revel

was a Yorta Yorta man while Cooper and Pease share Nyoongar heritage. Revel Cooper is recognised as an artistic influence on both Onus and Pease. For more on Onus's connection to Cooper, see Kleinert, S. 2010, 'Aboriginal enterprises: negotiating an urban Aboriginality', Aboriginal History, vol. 34, pp. 171-96. 
Cooper, along with many other Nyoongar children, was forced to live on the Carrolup Native Settlement, ${ }^{70}$ at Marribank in the southern wheatbelt of Western Australia. It was here, as a child, that he first learned to draw and paint. Key features of Cooper's painting find precedent in this earlier 'Carrolup School' style, which was rich in silhouetted trees, native animals and receding roads that represented 'the world they knew from their own experience'. ${ }^{71}$ Many of the Carrolup artworks were noted for their 'balanced composition... sure handling of movement and the true sense of perspective'.$^{72}$ This paintingmade when Cooper was an adult - reflects a maturity and a strength of technical skill that came through years of dedicated art practice.

It has been suggested that the bush landscapes of south-west Western Australia that are the focus of the Carrolup art movement resonate with a yearning for the world outside the settlement: 'We could speak of their attempt to escape through art into a world far removed from the actuality in which they found themselves. ${ }^{73}$ John Stanton has noted that the conditions of institutionalised settlement life encountered at Carrolup can be seen to parallel those observed in prison. And it was in such circumstances of incarceration that Cooper spent many years of his life. In fact, he also produced several artworks from Fremantle Prison, remarking: 'I paint mostly from memory...I'm happy painting whether I'm in here or outside. ${ }^{.74}$

Cooper's experience highlights the significance of mobility for Aboriginal people at a time when their movement was controlled and curtailed. In this regard art and automobility might serve a common aim: to escape, to move through, to travel the physical landscape of space and the imaginative landscape of the mind. Fellow artist Primus Ugle's words bring another dimension to Cooper's roadscapes and the potential significance of the road motif in earlier Carrolup art: 'We skipped over towns back in those years, skipped over them...back in the '40s, '50s, yeah, I remember it all, it was safer for us, safer for us to keep going. And not to stop. ${ }^{\prime 75}$ Ugle's recollection highlights the importance of the motor car in maintaining the security of Nyoongar families. It is relevant here to link Cooper's visual integration of the road and bush with the pragmatic importance of mobility to Nyoongar people and their experience of country. Cooper's own

\footnotetext{
70 The Carrolup Native Settlement was established in 1915 before temporarily closing in 1922. The institution was reopened in 1940 and the Carrolup art movement began in 1945 under the encouragement of headmaster, Noel White, and continued until Carrolup closed permanently in 1951. Stanton, J. E. 1992, Nyungar landscapes: Aboriginal artists of the south-west-the heritage of Carrolup, Western Australia, Occasional Paper No. 3, Berndt Museum of Anthropology, University of Western Australia, Perth.

71 Ibid., p. 13.

72 The Great Southern Herald, quoted in ibid., p. 16.

73 Phillips and Berndt, quoted in ibid., p. 14.

74 Revel Cooper, quoted in Schmitt, Hugh 1974, 'Revel finds a cause', Herald [Melbourne], 28 November, p. 12.

75 Primus Ugle quoted in Stanton, On track: contemporary Aboriginal art from Western Australia, p.14.
} 
practice speaks of the potential for realising a vision and connection with country, through art and memory, even where the artist is directly displaced from it. ${ }^{76}$

If Cooper's painting communicates something of the intermittence and movement of Nyoongar people through Country-landscape as moving picture - then Christopher Pease's urban roadscape conveys an effort to consolidate Aboriginal presence, over time, in place.

Nyoongar Dreaming is a dramatic and moody representation of a particular stretch of road in urban East Perth, Western Australia. Although the stillness, austere geometry and amorphous landmarks give the scene an air of anonymity, this is not just any road. In fact, as the title suggests, it is a place of Nyoongar significance. This is made evident by the Nyoongar man standing in the centre of the road and the lemon-lime sunset reminiscent of the vibrant Carrolup style. ${ }^{77}$

\section{Beneath the Bitumen: Nyoongar Dreaming (1999)}

The image depicts Nyoongar artist Peter Farmer standing in the centre lane of East Parade near the turn-off to a newly constructed freeway. This major transport artery skirts the edge of metropolitan Perth and is named after Peter Farmer's uncle, football legend Graham 'Polly' Farmer. The road Pease depicts is incomplete; there are no signs or lights; the freshly painted arrows and lines are the only indications. Incomplete that is but for Peter Farmer, who stands resolutely facing the viewer, both occupying the road and watching over it. Unlike the signals he replaces, Farmer does not stop or block our view, nor does he guide our direction onwards. His presence arrests the eye and raises questions in the viewer. Who is this man? And what is he doing standing at the intersection of a freeway? Farmer's position is disarming - this is not where we expect a person to stand-and it is welcoming; he is the only sign of life in a surreally still inner-city desert lit by an electric-green sky.

It is this sight of Farmer - simultaneously unsettling and comforting - that brings the work its gravitas and meaning. The eerie emptiness of the urban environs occupied by Peter Farmer speaks to what Byrne and Houston identify as the work's capacity to capture "both the "presence" and "absence" of Aboriginal culture, memory and history in Perth's contemporary inner city landscape'.$^{78}$ As

\footnotetext{
76 Similarly, Alison French has spoken of how Albert Namatjira's "watercolours generate journeys: cruising country of the mind and spirit." French, Alison 2005 'From camel 'boy' to flash Dodge 'driver'? The role of transport in the art and life of Albert Namatjira and its misrepresentation in the public domain', unpublished conference paper, Cruising Country symposium, Canberra.

77 In addition to other Nyoongar artworks, Pease's painting might be drawn into comparison with the many roadscapes of non-Indigenous artist Jeffrey Smart-as Brenda Croft points out ('Albert's gift', p. 87).

78 Byrne, J. and Houston, D. 2005, 'Ghosts in the city: multicultural redevelopment and urban memory in East Perth', in D. Cryle and J. Hillier (eds), Consent and Consensus: Politics, media and governance in twentieth century Australia, Common Cultures Series, API Network, Perth, pp. 319-49.
} 
well as being a portrait of a place, a person, an identity and a road, this painting reflects a historical moment in the redevelopment of East Perth and it makes reference to a much longer history that lies beneath the bitumen.

Pease's decision to represent the freeway after it is built but prior to its completion lends the painting a liminal quality, a state of 'in-between-ness' that is no doubt intentional. Curator Clotilde Bullen suggests that this unresolved road 'is a metaphor for unfinished business' ${ }^{\prime 79}$ that relates to the fact that the road runs through Nyoongar land, usurped first in the early settlement of the Swan River Colony (Perth) and once again for the East Perth Redevelopment Project. Like many road construction projects, the building of this freeway was highly contentious. It formed part of a broader 'urban renewal' scheme that displaced contemporary Aboriginal, immigrant and working-class people and masked their attachments and memories of the area through urban design and marketing materials. ${ }^{80}$ The 'space that was once an inner city industrial enclave and a contiguous Aboriginal cultural landscape - a site of both everyday inhabitation and spiritual significance ${ }^{81}$ was sold off to residents looking for a fashionably hip community. Pease's 'roadwork' addresses automobility in its most contemporary conceptualisation: as a system of car and driver, material infrastructure and regulations that collectively "may be seen to function as "technologies of government" which translate political rationalities and shape the performances and movements of drivers, vehicles, and the spaces of the road' ${ }^{82}$

Although it is not necessary to understand the contested nature of the Graham Farmer Freeway to gain something from Pease's painting, this background does illuminate the political nature of the painting. This political energy extends to broader issues of native title, land rights, spatial governance and the politics of 'naming' places. In bringing Graham Farmer's nephew into the frame, Pease humanises the road - establishing the Nyoongar identity of the man after whom the freeway is named. In doing so, he reminds us that this is not merely a road but a place that was and is inhabited by Aboriginal people. And this is perhaps where Pease's use of the road is most striking. By signalling that the freewaythe leitmotif of high modernity - is also a site of Aboriginal belonging, Pease bypasses the trappings of 'deep time' that have consigned Aboriginal people and their ancestral connections to Country to the pre-colonial past. In this regard, the road is no idle signifier. It is contested, not only because it is an expression of land; it indicates that the lived attachment to that land is experienced now.

century Australia, Common Cultures Series, API Network, Perth, pp. 319-49.

79 Clothide Bullen quoted in Watson, B. 2009, 'Public works: Nyoongar Dreaming', The Australian, 19 December.

80 Byrne and Houston, 'Ghosts in the city'.

81 Ibid., p. 3.

82 Merriman, P. 2006, “"Mirror, signal, manoeuvre": assembling and governing the motorway driver in late 1950s Britain', Sociological Review, vol. 54, p. 77. 
In making the road a centrepiece of the canvas, we cannot ignore the blackness of the ground on which Farmer stands. This is the freeway made flesh, and the cityscape reclaimed as Nyoongar Country, in man and name.

\section{Through the Mirror: Road to Redfern (1988)}

While the road in Nyoongar Dreaming has a stability and weight anchored in a documentary orientation, Lin Onus's road is unseen and illusory. Road to Redfern (1988) is an unusual composition that represents the view through the driver's side window. ${ }^{83}$ A large rectangular wing mirror projects from the bottom left corner of the painting, creating the illusion that we, the viewers, are driving in a vehicle. ${ }^{84}$ Looking out beyond the mirror, we can see a field of pale yellow-grey grasses beneath a clear, blue sky. The rolling contours of this land are echoed in three pairs of unfurled ribbon - red, yellow and black-flowing freely from the vehicle's mirror in the centre foreground. The ribbons are uplifted by the vehicle's motion, like an Aboriginal flag carried on the wind. Although they are attached and streaming from the mirror, the ribbons also appear to intermingle with the undulating terrain behind. In this instant of automobility, the fabric of the vehicle and the land become one.

The side rearview mirror is a compelling feature of Road to Redfern. Its size and shape resemble a truck mirror, but they also evoke the proportions and orientation of an Arnhem Land bark painting. This is made all the more apparent by the detail that appears within its frame: a black-and-white snake winding its way across a ground of rarrk - the pattern of fine cross-hatching integral to this art form. Yet if we are to read this rectangular shape also as a mirror then this image is a reflection of the view behind us. The snake is actually the road on which we are travelling and whose movements are echoed in the undulating hills of the country. To make this allusion stronger, Onus has cleverly designed the snake's head to look like a car. Is this the serpentine figure that underpins so many Aboriginal lands and beliefs? Is this a trick of the eye, a moment of whiteline fever? This is precisely the kind of double entendre for which Onus's work is famous. Thus, the painting becomes an image of the road as a living entity and the driving experience as an awakened encounter.

If we examine closely the surrounding vegetation, we might discern that the field is made up of fine crisscrossing lines. In painting the grasses in this manner, Onus links the rhythmic growth of the landscape to the cross-hatching patterns found in the bark/mirror. These, then, are two corresponding yet alternative visions of the one landscape, mutually reflective. Onus's innovative application

83 According to Donna Leslie, this is the view from the artist's four-wheel-drive.

84 Although Leslie suggests the vehicle in question is a four-wheel-drive, the dimensions and size of the mirror are more likely those of a truck. 
of multiple systems of representation allows for the presence of different realities of Country. ${ }^{85}$ Perhaps as a Yorta Yorta man with exposure to a large store of cross-cultural art influences, Onus is suggesting that there are various ways of experiencing, seeing and representing Country.

Such propositions and witty visual illusions are common in Onus's work and reflect the power of his process of juxtaposition to 'unsettle the natural or established order of things, to subvert conventional expectations' ${ }^{86}$ Road to Redfern is in keeping with this ability to cleverly synergise different visual traditions within the single composition. In this roadscape, Onus manages to integrate narrative and symbolism and to create a sense of simultaneously moving forward and reflecting back. In so doing, Onus manages to capture the phenomenological experience that comes with automobility, the timespace distanciation, the impressionistic thoughts and feelings that seem to pass through the body as it travels. He also realises the sensory atmosphere of driving: the wind, the speed, the clear light and air and the distinct visual nature of country glimpsed through a moving vehicle, the fact that you can see detail in the foreground, though distant features are blurred.

Onus created this painting in 1988, and its title is no doubt indicative of his own journey to attend Australia Day protests in Sydney. ${ }^{87}$ In a less literal sense, it alludes, as Donna Leslie points out, to the path of 'Aboriginal history as a story of survival' and Onus's own 'lifelong awareness of political reality and its collective challenge' ${ }^{88}$ Consequently, what the painting conveys is both light-hearted and deep, the sacred embedded in the everyday. Painted in the Australian bicentennial year, it cleverly poses the question of where Australians are, where we are going and where we have been.

\section{Going Places: The journeys of Ian Abdulla}

The individual paintings described above go some way towards indicating the scope and potential of the 'roadworks' theme to illuminate Aboriginal experiences of Country and automobility. I now want to home in on the work of one particular artist for whom automobility has been an enduring subject.

\footnotetext{
85 Neale, Margo (ed.) 2000, Urban Dingo: the Art of Lin Onus 1948-1996, Craftsman House, Sydney.

86 Ted Gott quoted in Neale, M. 2000, 'Lin Onus', Artlink, vol. 20, no. 1, <http://www.artlink.com.au/ articles/1394/lin-onus>

87 Redfern is an inner-city suburb of Sydney. It has a large Aboriginal community and is recognised historically as an epicentre of Aboriginal activism, resistance and enterprise. It was from here that the 26 January 1988 Invasion Day protest march, attended by Onus, commenced. 'All roads lead to Redfern, if you're black', according to Sonya Brindel, a participant in the Redfern Oral History Project (viewed 25 September 2011, <http://www.redfernoralhistory.org/Home/tabid/36/Default.aspx >).

88 Leslie, Donna 2001, 'A boriginal Art and Healing', in C. Rayment, (ed.) Sighs Too Deep for Tears, RLA Press (USydney) Sydney, p. 22.
} 
To my mind, no other Australian artist has represented automobility with such sincerity and concerted attention as the late Ngarrindjeri artist Ian Abdulla. Viewers familiar with his art will know that there is a strong current flowing through the opus of his life in paint: the River Murray. And while it is clear that the Murray sustained Abdulla and his family, shaped his daily life and deeply influenced his art, I would suggest that there is another corridor via which we might experience Abdulla's stories. Together these two courses - the river and the road-frame the country we have come to know through Abdulla's oeuvre. They are complementary flows. Like the diurnal rhythms within which his stories are set, they mingle together.

The importance of the road and the river to Abdulla might be measured not only in the regularity by which they were painted by him but also by the sheer expansiveness of their presence. Rarely does the canvas contain the course of either. Instead, both flow beyond the picture plane of a single work, into another and another, so that collectively Abdulla's oeuvre might be seen as a vast map ${ }^{89}$ made up of tributaries of water and bitumen. This network of black and blue is Abdulla's Country and it represents the history of his life in the Riverina of South Australia.

Each of Abdulla's paintings depicts an episode from his life, from his childhood in the 1950s through to his adult years. Abdulla's style of painting has been described as naive, and although it is generally figurative, many of the features in his landscapes are almost abstracted. The stars of the sky are yellow dots, the trees and bushes blocks of colour. His process of mapping Country through visual narratives is reinforced by a characteristic use of bird's-eye perspective and text at the top of the canvas to direct the plot. ${ }^{90}$ In this way, Abdulla's oral and visual recollections play out distinctively and complementarily, entwined in the same picture plane. As such, his series of works offers a different perspective on the road to those artworks discussed above. Instead of being brought into the space of the road, car and driver, and the immediacy of the automobile experience, the viewer is kept at some distance to the scene depicted. This is a clever visual cue that conveys a temporal detachment between the viewer and the incident. Abdulla is clearly reflecting on his past and we are invited to share in the reminiscences.

It is clear that Abdulla is on the move when we see where these stories are formed. His voice, hovering as text in the sky above, tells us the places to which

\footnotetext{
89 My reading of Abdulla's corpus as a vast map is influenced by Abdulla's use of text to denote places, people and activities within the image. The narrative quality of his texts are also complementary with reading his art practice alongside the road movie genre.

90 Floating text is central to the composition and narrative tone of Abdulla's art, for more discussion of this device in Abdulla's work see Fox, Stephen, Abdulla, Ian and Maughan, Janet 2004, Ian W. Abdulla: Elvis Has Entered the Building, Wakefield Press: Adelaide.
} 
he is going: Marree, Loxton, Winkie, Gerard Mission and so on. The car and the road are key subjects in many of these recollections. Even where they are incidental to the stated narrative, the presence of the road or car implicitly asserts it was the means by which the narrative was made possible.

Whether it is parked or moving, the vehicle is the agent through which we encounter many episodes in Abdulla's life. Often these moments are lighthearted and nostalgic reminiscences of youth, such as the drive-ins at Barmera, ${ }^{91}$ spotlighting for rabbits ${ }^{92}$ or having a few beers by the River Murray. ${ }^{93}$ And through an honest and open style, Abdulla engages the viewer to join him on the journey. With him, we attend the movies and go to the races, the oval to play baseball or to the river to catch fish. ${ }^{94}$ These are spaces that we share with mates, girlfriends, brothers, aunties and uncles, and they are moments where Abdulla reflects on life, sees God and misses his children. ${ }^{95}$ They also reveal, in addition to times spent fishing and hunting, something of his life working on the farms of the Riverina, for the Government and as a ranger monitoring the duck-shooting season and counting wildlife. ${ }^{96}$ There are times when the narrative explicitly concerns driving, as in the episode when his V8 Valiant cut out in Me and my step-brother coming down... (2009).

Abdulla's narratives of driving capture the mood within the car, the sociality of driving, the funny instances shared and the unusual sights witnessed:

One day the kid's Mother and myself were driving along the road on a Sunday's drive when one of the girls seen this bull mounting this cow and she said Mum why is that cow pushing the other cow well I couldn't drive any longer well I had to pullover and have a good laugh. ${ }^{97}$

Yet as often as he depicted the landscape in motion, Abdulla represented the car as stationary. These episodes are moments of stillness and reflection, when he sits on his car watching the cockatoos in the trees ${ }^{98}$ or thinking about his children. ${ }^{99}$ These roadworks offer poignant and magical visions such as the time when the artist shone his spotlight on the middle of the oval and saw three female kangaroos and a joey feeding. ${ }^{100}$ In painting these moments, Abdulla captures

\footnotetext{
Watching pictures at Barmera drivin (1998).

Spot lighting at night for rabbits (2009).

Me and my partner haveing a few beers by the River Murray (2010).

Watching the T's at gawlar (2009).

My cousin and uncle's come down from Cooberpedy (2009).

Swapping Tins of Bully Beef for Local Food (1994); Duck Shooters (2008); Counting Wildlife at Night (2001).

Cow pushing the other cow (1995).

Sitting on the tailboard (2009).

Thinking of my children... seeing God speak to one of his followers (1997); Thinking of my children (2002).

100 Travelling out to Gerrard Mission... (2009).
} 
the serendipity of driving, the things you encounter on your journey. ${ }^{101}$ Such unforgettable events are not always pleasant but Abdulla does not shield us from their view. ${ }^{102}$

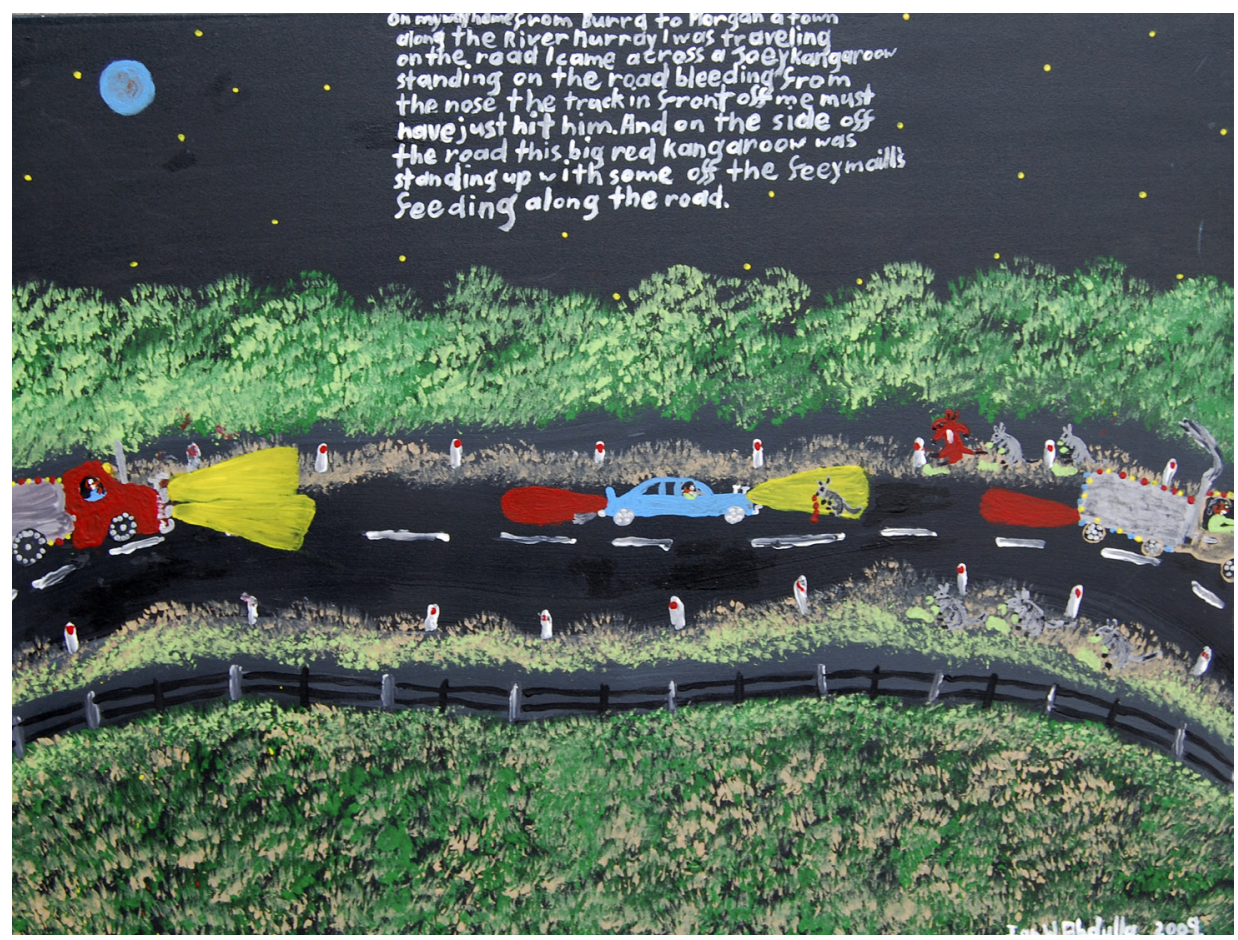

Figure 1 Ian Abdulla, On my way home from Burra... (2009)

Image reproduced courtesy of A. P. Bond on behalf of the artist's estate

In this respect, Abdulla is not uncritical in his depiction of the consequences of automobility. In On my way home from Burra... (2009), he recalls the sight of an injured kangaroo (Figure 6.4), and in other works he reveals the difficult circumstances to which being automobile can lead. This is, in fact, an important aspect of Country that Abdulla's automobility lays bare: the fault lines of racism and inequality that underlie many parts of social relations in Australia. No blacks in this town (2001) makes this obvious through text, when a white woman suggests that Abdulla and his mate park on the outskirts instead of in the town centre. But it is also implied visually as in Collecting botteles along the road, in which the white waterskiers on the river run adjacent to 'some of us

101 On My Way Home Seen This Big Red Kangaroos (2008); Evil Spirits left my body (1991).

102 On my way home from Burra to Morgan... (2009). 
boys...collecting botteles along the road' to beat 'the hard times' ${ }^{103}$ The leisure activities of white people are juxtaposed with the efforts Abdulla's family has to make to simply survive.

Almost as frequently as he is represented driving through the landscape, Abdulla also appears walking along the road. ${ }^{104}$ In doing so, he captures the realities of automobility that rarely rate mention: the social inequalities of car ownership, and the fact that cars shape the lives of even those who are not 'explicitly automobilized'. ${ }^{105}$ Indeed, Abdulla's stories of being without a vehicle reveal other aspects of life in the country: taxis delivering sly grog; walking home with his dog, Skip; hitchhiking back from the pictures; being parched and covered in dust; or being picked up by the cops and having his kids left stranded on the footpath. ${ }^{106}$

Abdulla's paintings have been appreciated for their optimism, and there is no doubt his stories are often humorous, detailing good times and ripping yarns:

One night when we were out spotlighting we got bogged down in the soft sand so we tried to push the station wagon of mine out and while we were doing this we could hear voices in the dark well we soon got the wagon out cause we knew that the voices were the sound of ghosts in the night so we didn't go back there again. ${ }^{107}$

Many of his vignettes, however, also reveal the injustices he and other Ngarrindjeri people faced as well as depicting how Ngarrindjeri people utilised the country, and how they relied on its sustenance to stay alive. ${ }^{108}$ The joys of car camping with his family at Katarrapka Creek are tempered by the knowledge that this was 'be for we had to pay money to camp... be fore white man stole our Land'. ${ }^{109}$ Many of his roadworks possess a political flavour or a concern for the state of the land, precisely because of what he notices during his road trips: 'Here I am on my home... Now all I see is no water and dead Native Wildlife'. ${ }^{110}$

Abdulla's treatment of the car, like the other subjects he depicts, is loose and generalised. He shows the barest of details: the windows, the steering wheel,

\footnotetext{
103 Collecting botteles along the road (2005).

104 Itchikinging home from the picher at night (2010); Me and all the boys going home after a day of hunting (2010); Walcking home with some Rabbits... (2009); Walking home with two of my mats (2010).

105 Sheller, M. 2008, 'Bodies, cybercars and the production of automated-mobilities', Social and Cultural Geography, vol. 8, no. 2, p. 175.

106 Getting hows flagons from a white taxi driver (2010); Itchikinging home from the picher at night (2010); One night the Berri cops come out (2009); Me and my dog skip... (2010).

107 Hearing voices in the night (1995).

108 Many of Abdulla's paintings demonstrate this point; examples include: Catching Yabby in the Backwaters of The River Murray (2008); Me and My Brother Fishing (2003); Shooting Kungari (1994); Weighing the Pondi (2002).

109 Camping before the white man stole our land (1999).

110 Here I am on my home I was haveing... (2009).
} 
the bumper, the aerial, the tyres and wheel nuts. But the most striking feature of Abdulla's vehicles is the light they cast in the darkness. Anyone who has ever watched a car move through the country at night will recognise the accuracy of Abdulla's observations, with their vibrant beam lighting the way forward. These same spotlights, which illuminate so many of Abdulla's Riverina narratives, are 'defected' by the police when he drives the streets of Adelaide. ${ }^{111}$ If you are black be proud... (2009) is something of a revelation about Abdulla's own sense of belonging: 'You see Im from the country I'v all ways felt verey touchy about the police in Adelaide.' While this painting serves to highlight how Abdulla experienced differences in driving in the city and the country, at the same time it builds a bridge over that dichotomy of urban and bush as separate terrains of Aboriginal dwelling.

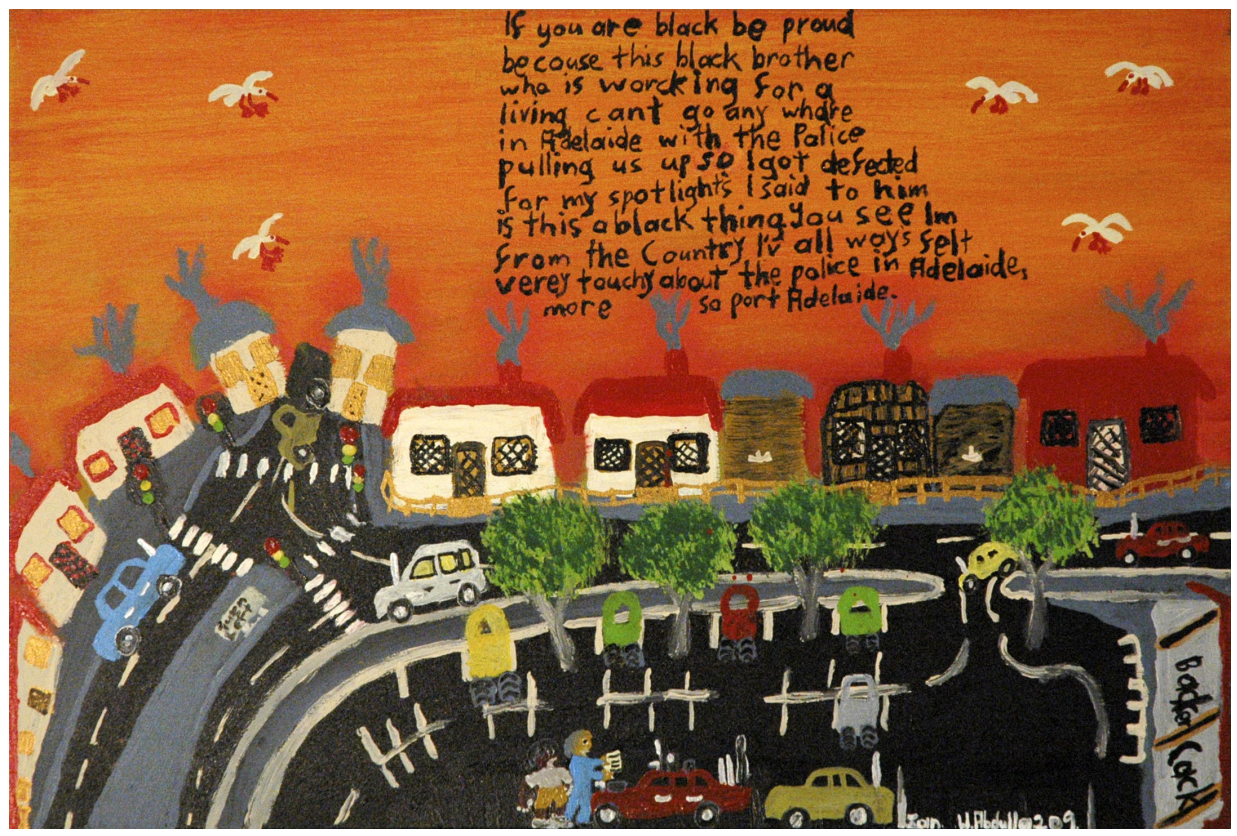

Figure 2 lan Abdulla, If you are black be proud... (2009)

Image reproduced courtesy of A. P. Bond on behalf of the artist's estate

In keeping with the theme of this issue, it is worth noting that Abdulla's roadworks encompass urban environments, rural towns, back roads and beaten tracks. He presents a broad scope of what it means to be automobile in different

111 In this painting, Abdulla touches on another aspect of race: law and order, where automobility might also be perceived as a threat to order in so far as the ability to locate, know the whereabouts of and contain Indigenous and minority peoples is a well-established protocol of government control. Concerns over racial profiling of drivers by police have been raised in the United States - most famously in the case of Rodney King. 
situations, as well as what it means to be without wheels. As such, Abdulla's unique autobiographical narratives represent different aspects of automobility and the subjectivities it produces.

The mood he captures with his big skies and tiny people communicates a vision of the driver as being enveloped by the landscape. The detailed mapping that Abdulla's roadworks represent tells the great journey of his life. It includes the people - black and white - and the moments from different stages of his life. It might well be considered what Gelder calls 'a practice of repossession in the context of dispossession'. ${ }^{112}$ Abdulla's landscapes are rarely unpeopled. Cars, humans, birds, trees and kangaroos all come together in an ecology of the road that is both uplifting and poignant. This body of work reflects the reality of automobility in all its devastating potential: political, tragic, captivating, liberating, painful, humorous and mythic. Yet, as we contemplate the network of roads that runs through Abdulla's corpus, it is impossible to forget Abdulla's rendering of the river. Its course across the canvas is echoed in the bends of the road. And that is why his work is such a compelling insight into the art of automobility as Country.

\section{Driving Home}

I began this essay by considering the emphasis on Country in contemporary Aboriginal art discourse. By now I hope it is clear that automobility is an undeniable, though at times ineffable, force in the mediation and maintenance of Aboriginal relations to kin and Country, and its communication in art. While I hope to have demonstrated that the Aboriginal art of automobility - what I have called roadworks - is a prolific and engaging theme, I have also signalled that more attention to this theme is warranted. I have only stirred the surface of the dirt, the bitumen and the gravel that make up these Country roads. Nevertheless, the artworks I have touched upon illuminate important aspects of Aboriginal experiences of automobility and Country. For a start, they show us histories of automobility that counterbalance the dominant images of European exploration, modernity and Western progress. Such histories show particular places and travels as evidence of how Aboriginal people have continued to maintain connections to Country despite the pressures of dispossession, trauma, social struggle and incarceration.

Not surprisingly, some of these artworks are insistently political. Yet in symbolic terms Aboriginal automobility is always politicised because since the advent of mass motorisation, 'driving and car ownership were anchored

112 Gelder, 'Mad Max and Aboriginal automation', p. 61. 
by themes of competence and self-determination; the figures of the driver and the citizen were regularly conflated' ${ }^{113}$ The 'right to drive' and move about at one's own discretion carries added relevance for those previously denied such possibilities. ${ }^{114}$ Pictured in this way, the very act of driving might constitute a political redress to the history of dispossession, confinement and regulation that many Aboriginal Australians have experienced. Moreover, stories and scenes of Aboriginal automobility might be seen to counter-map the cadastral boundaries and surfaces written by the dominant white culture. ${ }^{115}$ Aboriginal automobility offers a means for reinscribing these maps with an Indigenous geography that comprises Aboriginal histories, people and pathways - and which, like Pease's, Cooper's and Onus's paintings, speaks of the realities of Aboriginal experience: absence as well as presence, flight and captivity, the sacredness and the mundaneness of living. Abdulla's vast road network-made up of paintings, drawings, stories and installations - is precisely the kind of reconfigured road directory that way-marks Aboriginality within the Riverina.

Automobilities involve complex geographies comprising humans and non-human agents that are consistent with Aboriginal ontologies of place as connected and connecting and which 'enable people and materials to move and to hold their shape as they move across various regions' ${ }^{116}$ Likewise, the framework of automobility might be seen to support a logic of Country where place is both enduring and emergent, and because 'places themselves can be seen as becoming or traveling, slowly or quickly, through greater or shorter distances... Places are about relationships, about the placing of peoples, materials, images and the systems of difference that they perform'. ${ }^{117}$

Roadworks might be seen as narratives of Country that are conducive to the movement and regenerative dynamism of an ancestrally ordained system. They tell an important part of the recent histories of Aboriginal people and their contemporary relations. In contradistinction to those theorists who emphasise the banality of the road, the boredom and the detached 'place-less-ness' of the driving experience, the Aboriginal art of automobility suggests another view, another subjectivity and another type of journey entirely. They quite literally mobilise the representation of Aboriginal identities along new paths, further

\footnotetext{
113 Seiler, Republic of Drivers, p. 109. One might consider as a specifically Australian example the experience of Albert Namatjira (see Croft, 'Albert's gift').

114 As Paul Gilroy adds in the context of African Americans, the histories of confinement and coercion must have given black Americans 'additional receptivity to the pleasures of auto-autonomy as a means of escape, transcendence and even resistance'. Gilroy, 'Driving while black', p. 84.

115 On the importance of counter-mapping in Aboriginal heritage and archaeology, see Byrne, D. 2008, 'Counter-mapping: New South Wales \& Southeast Asia', Transforming Cultures eJournal, vol. 3, no 1 (February), <http://epress.lib.uts.edu.au/journals/TfC >

116 Hannam, K., Sheller, M. and Urry, J. 2006, 'Editorial: mobilities, immobilities and moorings', Mobilities, vol. 1 , no. 1 , p. 14

117 Ibid., p. 13.
} 
destabilising outmoded conceptions of culture as ancient and unchanging. Roadworks reconnect the routes of the traditional with the contemporary, and the urban with the outback, thereby overriding the many defunct dichotomies that have inaccurately defined Aboriginal art and identity.

Finally, the art of automobility chimes with an Aboriginal sensibility of Country because it embraces 'mobile, dynamic and relational accounts of space and place', ${ }^{118}$ which should be seen to complement rather than oppose more rooted perceptions of time and place. Perhaps most importantly in the context of Australian art, roadworks demonstrate that identity creation, maintenance practices and notions of home are not construed statically. Dwelling within and belonging to Country can be served equally through motion. ${ }^{119}$

\footnotetext{
118 Merriman, P. 2004, 'Driving places: Marc Augé, non-places, and the geographies of England's M1 Motorway', Theory, Culture \& Society, vol. 21, nos 4-5, p. 145.

119 I would like to thank Alison French, Lisa Stefanoff and two anonymous reviewers for their comments on an earlier draft of this paper.
} 